\title{
The Influence on Teacher Professionalism of Educational Qualifications and Teaching Experience
}

\author{
${ }^{1}$ SD Negeri Jebang, Indonesia \\ ${ }^{2}$ Universitas PGRI Palembang, Indonesia \\ *Corresponding author. Email: winartanartadiah@gmail.com
}

\begin{abstract}
The goal of this study is to identify and evaluate the influence of educational qualifications and teaching experience on the professionalism of public elementary school teachers in the district of Plakat Tinggi. This type of study is quantitatively descriptive. The sample in the study consisted of 85 respondents with data collection techniques in the form of a questionnaire (questionnaire). The findings showed that: 1) there is a significant impact of educational qualifications on the professionalism of teachers; 2) there is a significant effect of teaching experience on the professionalism of teachers; 3) there is a significant influence on the professionalism of teachers between educational qualifications and teaching experience.
\end{abstract}

Keywords: Teacher Professionalism, Educational Qualifications, Teaching Experience

\section{INTRODUCTION}

Improving the standard of learning programs must be focused on a structured approach to teaching and learning activities. The need for help in attempts to make use of learning opportunities. The greatest deficiency of our educational and learning institutions is that education does not have a strong foundation for cultural growth. The educational process is a public process [1]. Our educational institutions are built only on the basis of an economic model for producing/cultivating human workers who have been controlled on the basis of an economic value system of background, so it is not shocking that our educational production becomes job-seekers and powerless, not innovative people who build welfare ties in the cycle of benefits. Which is expected to be the most unforgettable and important thing in education and learning. Dewantara claimed that education generally means an effort to foster the growth of the character, inner power, character, intellectual mind, and body of Munib children, 2007 [2].

According to Ahmad [3], professional and highquality employees are working in different sectors of life. This rapidly rapid change calls for skilled and competent human capital. This rapidly rapid change calls for skilled and competent human capital. All such quality human capital has an important role to play in the progress of sustainable growth. Training from elementary school to tertiary levelis required to develop technical human capital.
Education is the most significant predictor for the growth of a nation [4]. Improving the standard of education is a primary agenda for education in Indonesia. In the sense of quality education, of course, it cannot be isolated from the positions of the different parties, one of which is the role of educational workers. Education is considered to have a very central role to play in the process of nation building. According to Law 20, Article 3 of 2003 on the National Education System, it is mentioned that national education functions to build the capacity and form the character and civilization of a nation with dignity in the sense of the education of the nation. However, it is definitely not easy to meet these standards, since there are several factors that have always been a hindrance, such as poverty, underdevelopment and even cultural chaos[5].

It also depends on the expertise and level of education they take to become a skilled teacher, since the teaching role is one of the professional positions. Professional refers to a role or position that needs knowledge, commitment and professional loyalty. A theoretical career cannot be practiced by someone who is not educated or qualified for it. In Permendiknas Number 16 of 2007, there are four competency levels for elementary school teachers, namely pedagogical, personal, social and professional competence. Teacher competencies include pedagogical, personal, social and professional competencies gained through vocational education [6].If the instructor masters the four competencies, it can be assumed that he is a competent 
teacher with a national level. In order to be able to master these four competencies, teachers need to increase their level of education because, in 2007, the Minister of National Education through Permendiknas Number 16 of 2007 set requirements for academic qualifications and teacher competencies. Teachers at $\mathrm{SD} / \mathrm{MI}$, or other comparable types, must have a minimum education qualification of diploma four (DIV) or a bachelor's degree (S1) in SD/MI education (DIV/S1 PGSD/PGMI) or a psychology degree from an approved program of study[7].

Research conducted previously by Marce et al [8] describes the factors that hinder the professionalism of teachers in the performance of learning media so that teachers can perform their duties properly and achieve full results, the Principal should hold briefings and training sessions for teachers and training staff on the use and mastery of education technology, and the Teachers' focus should be on the use and mastery of education technology.One attempt to improve professionalism and evaluate the performance of teachers is to undertake academic supervision, so the principals must have the expertise to perform academic supervision [9].

Preliminary findings of the researchers have shown that the low academic qualifications and the not adequate professional growth of elementary school teachers in Sungai Keruh District, Musi Banyuasin Regency and attitudes towards the teaching profession still need to be cultivated.

The low academic qualifications and lack of professional development of teachers in Sungai Keruh District, Musi Banyuasin Regency and attitudes towards the teaching profession still need to be cultivated. It appears to have consequences for the low skill of teachers, and it is feared that it would have more implications for the poorer quality of school learning. In order to be eligible to be said as a professional position, the teaching position must have the following requirements, as collected by the National Education Association (1948) cited by Soetjipto[10] a position involving intellectual practice, 2) a position dealing with a particular body of knowledge, 3) positions requiring a long period of professional preparation (compared to jobs requiring mere general training), 4) positions requiring continuous 'in-service training,' 5) positions which guarantee a life-long career and lifelong membership, 6) a position which sets out its own criteria (standards), 7) a position which is more concerned with service over personal interests,8) a role that has a strong and closely-knit professional organisation. It is evident from the above requirements that the teaching profession is very serious about the services that must be given to the community. Therefore, in order to preserve and improve services optimally and to prevent the community from being harmed by irresponsible individuals, a code of ethics is required for teachers. Teachers are a profession whose job is to carry out primary and secondary education by using a range of learning methods to fulfill their learning objectives [11].

In addition to the criteria for higher education, in order for teachers to become more skilled, each teacher must be actively involved in training/upgrading. For example, learning model training, teaching aids for the creation of training, development syllabus training and training of materials. Through this preparation, new knowledge and new teaching methods can be easily adopted by teachers so that they can increase the skills and experience of teachers in carrying out their work, as well as the results of the supervision of the Principal of the SD Sungai Keruh District, Musi Banyuasin Regency.

\section{METHODS}

According to Sukmadinata[12], the research method is a collection of methods or practices for conducting research based on basic assumptions, philosophic and ideological beliefs, questions and issues at hand. The research approach has a particular design for research. This research approach is quantitative research by explaining the results of the research.

Quantitative analysis is based on the theory of positivism, which emphasizes empirical phenomena and is quantitatively studied. The sample in this study is the SD Negeri in the Plakat Tinggi District, which is sampled in this study using objective sampling, that is to say, teachers who are used as research samples are teachers in each elementary school with a total of 85 teachers. Techniques are required for the collection of data, both techniques for the provision of data and techniques for the classification of data that have been collected. The same argument has also been made by Sugiyono[13] that the data collection approach is the method used to collect data, while the data collection methodology is the method used to carry out the method chosen to use questionnaire data and documentation. The data analysis methodology used in this study uses simple correlation and multiple regression data analysis techniques with the aid of SPSS For Windows Version 22. The implementation process of the research includes: (1) a descriptive analysis, (2) a test of the analysis criteria and (3) a test of the hypothesis.

\section{RESULTS AND DISCUSSION}

Hypothesis testing was continued after testing the data analysis requirements, namely the normality test and the homogeneity test. After the data is declared to have met the requirements to be tested, then the hypothesis is tested using the $\mathrm{t}$ test and the $\mathrm{F}$ test, to determine the effect partially and simultaneously on the variables to be tested. 
Table 1. Results of Multiple Correlation Statistical Analysis and Coefficient of Determination

\begin{tabular}{|l|c|c|c|c|}
\hline \multicolumn{5}{|c|}{ Model Summary $^{\mathbf{b}}$} \\
\hline Model & $\mathrm{R}$ & R Square & $\begin{array}{c}\text { Adjusted R } \\
\text { Square }\end{array}$ & $\begin{array}{c}\text { Std. Error of the } \\
\text { Estimate }\end{array}$ \\
\hline 1 & $.463^{\mathrm{a}}$ & .215 & .196 & 13.335 \\
\hline
\end{tabular}

Table 2. Results of the F Test Analysis

\begin{tabular}{|c|c|c|c|c|}
\hline \multicolumn{5}{|c|}{ Model Summary $^{\mathbf{b}}$} \\
\hline Model & $\mathrm{R}$ & R Square & $\begin{array}{l}\text { Adjusted R } \\
\text { Square }\end{array}$ & $\begin{array}{l}\text { Std. Error of the } \\
\text { Estimate }\end{array}$ \\
\hline 1 & $.463^{\mathrm{a}}$ & .215 & .196 & 13.335 \\
\hline \multicolumn{5}{|c|}{$\begin{array}{l}\text { a. Predictors: }(\text { Constant }) \text {, Teaching Experience }\left(\mathrm{X}_{2}\right) \text {, Educational } \\
\text { Qualifications }\left(\mathrm{X}_{1}\right)\end{array}$} \\
\hline b. Depe & lent $\mathrm{V}_{\mathrm{c}}$ & able: Teac & rofessionalism ( & \\
\hline
\end{tabular}

Table 3. Results of t test analysis

\begin{tabular}{|c|c|c|c|c|c|c|}
\hline \multicolumn{7}{|c|}{ Coefficients $^{\mathrm{a}}$} \\
\hline & \multirow{2}{*}{ Model } & \multicolumn{2}{|c|}{$\begin{array}{c}\text { Unstandardized } \\
\text { Coefficients }\end{array}$} & \multicolumn{3}{|c|}{$\begin{array}{c}\text { Standardized } \\
\text { Coefficients }\end{array}$} \\
\hline & & $\mathrm{B}$ & $\begin{array}{l}\text { Std. } \\
\text { Error }\end{array}$ & Beta & $\mathrm{t}$ & Sig. \\
\hline \multirow[t]{2}{*}{1} & (Constant) & 37.580 & 7.621 & & 4.931 & .000 \\
\hline & $\begin{array}{l}\text { Teaching Experience }\left(\mathrm{X}_{2}\right) \text {, } \\
\text { Educational Qualifications } \\
\left(\mathrm{X}_{1}\right)\end{array}$ & .406 & .129 & .462 & 3.136 & .003 \\
\hline
\end{tabular}

Based on the results of the review of the research data using version 22 of the SPSS program. Before the study was carried out, the data criteria, namely validation and reliability checks, were tested first. The data validity test was carried out using the validation test carried out with the validator, namely the PGRI Palembang University lecturer. Then proceed to verify the validity of the analysis using the SPSS software version 22 estimate. The results of the analysis validity measurement for the educational qualification variables remember that they are all correct for further testing of the statement objects. The results of the validity analysis calculation for the teaching experience variable note that all of them are accurate so that the statement items can be further checked. The results of the validation analysis calculation for the vector instructor professionalism show that all of them are correct so that the statement items can be further checked. The pre-requisite data test was then continued for the reliability test. After measurement using the SPSS version 22 program, it is recognized that the educational qualification variable had a value greater than the $r$ table, that the teaching experience variable was greater than the $r$ table, and that the teacher integrity variable had a value greater than the $r$ table, so that it could be concluded that all the research variables had been considered accurate.

\section{CONCLUSION}

On the basis of the results of the research that has been carried out, it can be concluded that the educational qualifications affect the professionalism of teachers on the basis of the results of the t-test study. This indicates that there is an impact of educational qualifications on the professionalism of elementary school teachers in the Plakat Tinggi sub-district, which was the response to the first hypothesis. Teaching experience has an effect on teacher professionalism based on the findings of the t-test study. This indicates that there is an impact of teaching experience on teaching professionalism in elementary schools in the Plakat Tinggi sub-district, which was addressed by the second hypothesis.

\section{AUTHORS' CONTRIBUTION}

Winarta: designed and performed experiments and analysed data. Edi Harapan and Tahrun: proofing 


\section{ACKNOWLEDGMENTS}

Thank you to your family and colleagues, the Chancellor of the PGRI Palembang University, the Director of the Postgraduate Program at PGRI Palembang University, the Chair of the PGRI Palembang University Education Management Masters Program and the supervisors who have contributed to the completion of this study journal. Then thank you, too, to the friends of PGRI Palembang University Postgraduate students and all those who helped to write and publish this journal.

\section{REFERENCES}

[1] Maseleno, A., Ayshwary, B., Ivanova, T. N., Hashim, W., Nguyen, P. T., Shankar, K., Kristiawan, M., Huda, M. (2019). General Theoretical and Philosophical Aspects of Modern Education. Aspectos Teóricos y Filosóficos Generales de la Educación Moderna. Revista San Gregorio 2019, No. 32 Special Issues August.

[2] Munib. (2007). Pengantar Ilmu Pendidikan;Introduction to Education Science]. Semarang: Universitas Negeri Semarang Press.

[3] Ahmad. (2016). Ketahan malangan Kepemimpinan Kepala Sekolah Salah Satu Faktor Penentu Keberhasilan Kepala Sekolah [Adverse Resilience of Principal Leadership is One Determining Factor of Principal's Success].Yogyakarta: Deepublish.

[4] Asvio, N., Yamin, M., \&Risnita. (2019). Influence of Leadership Style, Emotional Intelligence and Job Satisfaction toward Organizational Commitment (Survey at SMA Muhammadiyah South Sumatera). International Journal of Scientific \& Technology Research 8 (8).

[5] PermendiknasNomor $16 \quad$ Tahun 2007 tentangStandarKualifikasiAkademik dan Kompetensi Guru[Permendiknas Number 16 of 2007 concerning Academic Qualification Standards and Teacher Competencies].

[6] Turmini., Kristiawan, M., \& Sari, A. P. (2020). The Influence of Education, Training, and Experience towards Teacher's Professionalism. Electronic Research Journal of Social Sciences and Humanities Vol 2: Issue II. ISSN: 2706 - 8242

[7] Depdiknas. (2003). Undang-undang RI No.20 tahun 2003. TentangSistem Pendidikan Nasional [Law of the Republic of Indonesia No. 20 of 2003 on the national education system].

[8] Marce, S. Ahmad, S.\& Eddy. S. (2020). ManajemenKepemimpinanKepalaSekolahSebagai Administrator DalamPeningkatanKompetensi
Guru[Leadership Management of Principals as Administrators in Increasing Teacher Competence]. Islamic Education JurnalDawuh: Vol. 1, No. 2, Juli 2020.

[9] Khasanah, U., Kristiawan, M., \&Tobari. (2019). The Implementation of Principals' Academic Supervision in Improving Teachers' Professionalism in the State Primary Schools. International Journal of Scientific \& Technology Research, 8(8).

[10] Soetjipto. (2014). ProfesiKeguruan [Teaching Profession]. Jakarta: Rajawali Press.

[11] Rahmadoni, J., Arifnur, A. A., \&Wahyuni, U. M. (2020). Penerapan Schoology Sebagai Learning Management System Bagi Guru SMAN 1 Sutera [Implementation of Schoology as a Learning Management System for Teachers of SMAN 1 Sutera]. JurnalHilirisasi IPTEKS volume 3 No 2.

[12] Sukmadinata, N. S. (2015). MetodePenelitian Pendidikan [Educational Research Methods]. Bandung: RemajaRosdakarya.

[13] Sugiyono. (2018). MetodePenelitian Kuantitatif [Quantitative Research Methods]. Bandung: Alfabeta. 